\title{
USAGE PATTERN OF LIBRARY RESOURCES BY THE FACULTY MEMBERS OF NAAC ACCREDITED DEGREE COLLEGES IN KADAPA DISTRICT: A STUDY
}

\author{
Mr.M.V.Krishna Reddy \\ Assistant Librarian, Loyala Degree College, Pulivendula,Y.S. R. Kadapa District \\ Dr.M.Anjaiah \\ Assistant Professor, Dept. of Library \& Information Science, Dravidian University, Kuppam, \\ Chittoor District, A.P. \\ Dr.M.Doraswamy \\ Professor \& Head, Dept. of Library \& Information Science,Dravidian University, Kuppam, \\ Chittoor District, A.P.
}

Article DOI: https://doi.org/10.36713/epra4841

\section{INTRODUCTION}

Any library irrespective of its kind has to be user oriented. All the services provided by the library are intended for the benefit of the users. In order to improve the existing library services, planning for new services, rationalize the limited financial resources in an economic way, evaluate the performance of the library and enhance the user satisfaction, it is imperative to conduct user studies. These studies will help library authorities to know the utilization and satisfaction of users with existing library resources, services and facilities, the type of new services required and the amount of finance required for their implementation. Usage and satisfaction studies are also part of user studies as these are based on users. The performance of any library can be judged on the basis of extent of usage and satisfaction it is providing to its users. Hence, there is need to conduct user studies to assess the usage and satisfaction of users with the resource, services and facilities provided by the library. These studies are also essential to know the differences in satisfaction among the differences in usage and satisfaction among the different categories of users. Necessary measures can be taken in case of the users are dissatisfied with the library services and facilities by finding out the reasons for their dissatisfaction.
The present study makes an attempt in this direction by studying the usage pattern of library resources by the faculty members of NAAC accredited degree colleges in Kadapa District. Efforts have been made to know the differences in usage and satisfaction between the faculty members of NAAC degree college libraries and finally to make recommendations to improve the present library resources, services and facilities.

\section{OBJECTIVE OF THE STUDY}

- The main objective of the study is to study the usage levels on various library print resources such as books, journals/magazines, newspapers, question papers, project reports, and back volumes of periodicals reference books, made by the faculty members.

- Recommend concrete suggestions and recommendations to authorities for improving the library collection basin on inputs collected from faculty members.

\section{HYPOTHESIS OF THE STUDY}

- There would not be any significant differences in the usage level of various library resources between the male and 


\section{EPRA International Journal of Research and Development (IJRD)

female faculty members, and arts and science faculty members.

\section{METHODOLOGY}

In order to study the information used by faculty members of select NAAC accredited degree college libraries in Kadapa district of the state of Andhra
Pradesh in India. There are 94 different degree colleges (such as Government, Aided and Private) within the territorial jurisdiction of Kadapa district. Out of 94 degree colleges, 10 colleges have been accredited by NAAC. Hence, the researcher selected users from these ten colleges (list in Table 1) as the sample respondents in the first instance.

Table 1: List of Sample Colleges

\begin{tabular}{|c|l|c|}
\hline S.No & \multicolumn{1}{|c|}{ Name of the College } & Place \\
\hline 1 & C S S R \& S R AM Degree College & Kamalapuram \\
\hline 2 & Government Arts College for Men & Kadapa \\
\hline 3 & Government Degree College & Rajampet \\
\hline 4 & Government Degree College & Porumamilla \\
\hline 5 & Government Degree College & Jammalamadugu \\
\hline 6 & Government Degree College & Pulivendula \\
\hline 7 & Loyala Degree College & Badvel \\
\hline 8 & S B V R Degree College & Proddatur \\
\hline 9 & S C N R Government Degree College & Kadapa \\
\hline 10 & SKR \& SKR Government College for Women & \\
\hline
\end{tabular}

It is observed that there are four categories of users enrolled in the selected NAAC degree college libraries namely.

1. Undergraduate students

2. Post graduate students

3. Non-teaching staff; and

4. Faculty members

The present study is limited to survey of the users belonging to the faculty members only which is located in serial no.4 of the hierarchy.

At present, there are 335 faculty members are working in the selected ten NAAC accredited degree colleges in Kadapa district. Since the population is meager, the researcher has selected all the faculty members by following the census sampling method. The researcher distributed 335 questionnaires and received responses from 271 (81\%) faculty members only which include language teaching faculty members who are connected with arts and science stream. The inclusion of language teaching faculty in the sample is done due to the size of the sample is flimsy. Out 271, 174 male faculty members and 97 female faculty members; 86 are arts faculty members and 185 science faculty members.

\section{DATA ANALYSIS}

After collecting the data from the users of NAAC accredited degree colleges, the data is checked and analysed according to the objectives and hypothesis stated. First the data is recorded on the data sheets and then fed into the computer personally. The data has been tested with various statistical tools (Descriptive statistics and Chi-square test) by using the SPSS. If the observed frequency is less than five in any cell of row, that row is merged with its adjacent row while calculating chi-square value. However, some of the calculations are done with the help of a calculator. The data has been presented in the form of tables in the following paragraphs.

\section{UTILISATION OF LIBRARY RESOURCES AND SERVICES}

To know faculty usage level of different library print resources, namely books, journals/magazines, newspapers, question papers, project reports, and back volumes of periodicals were examined in the following paragraphs.

\subsection{Books}

The allocation of faculty members according to their level of usage of books in the library, in relation to gender and disciplines is displayed in Table 2. 


\section{EPRA International Journal of Research and Development (IJRD)}

Table 2: Allocation of faculty members according to the level of usage of books

\begin{tabular}{|c|c|c|c|c|c|}
\hline \multirow{2}{*}{ Level of use } & \multicolumn{2}{|c|}{ Gender } & \multicolumn{2}{|c|}{ Discipline } & \multirow{2}{*}{ Total } \\
\hline & Male & Female & Arts & Science & \\
\hline Highly & $\begin{array}{c}58 \\
(33.33) \\
\end{array}$ & $\begin{array}{c}31 \\
(31.96) \\
\end{array}$ & $\begin{array}{c}27 \\
(31.39) \\
\end{array}$ & $\begin{array}{c}62 \\
(33.51)\end{array}$ & $\begin{array}{c}89 \\
(32.84) \\
\end{array}$ \\
\hline Frequently & $\begin{array}{c}91 \\
(52.30)\end{array}$ & $\begin{array}{c}53 \\
(54.64)\end{array}$ & $\begin{array}{c}47 \\
(54.65)\end{array}$ & $\begin{array}{c}97 \\
(52.43)\end{array}$ & $\begin{array}{c}144 \\
(53.14)\end{array}$ \\
\hline Occasionally & $\begin{array}{c}17 \\
(9.77)\end{array}$ & $\begin{array}{c}8 \\
(8.25) \\
\end{array}$ & $\begin{array}{c}6 \\
(6.98) \\
\end{array}$ & $\begin{array}{c}19 \\
(10.27)\end{array}$ & $\begin{array}{c}25 \\
(9.22) \\
\end{array}$ \\
\hline Rarely & $(4.60)$ & $\begin{array}{c}5 \\
(5.15) \\
\end{array}$ & $\begin{array}{c}6 \\
(6.98) \\
\end{array}$ & $\begin{array}{c}7 \\
(3.79)\end{array}$ & $\begin{array}{c}13 \\
(4.80)\end{array}$ \\
\hline TOTAL & $\begin{array}{c}n=174 \\
(100.00)\end{array}$ & $\begin{array}{c}n=97 \\
(100.00)\end{array}$ & $\begin{array}{c}n=86 \\
(100.00)\end{array}$ & $\begin{array}{c}n=185 \\
(100.00)\end{array}$ & $\begin{array}{c}N=271 \\
(100.00)\end{array}$ \\
\hline \multicolumn{2}{|c|}{$\begin{array}{l}\chi^{2}(\text { Male- Female })=0.2968 \\
\chi^{2}(\text { Arts- Science })=2.0726\end{array}$} & $\begin{array}{ll}3 & \text { TV: } 7 \\
3 & \text { TV: } 7\end{array}$ & $\begin{array}{l}\text { Not Signif } \\
\text { Not Signif }\end{array}$ & $\begin{array}{l}\text { ant @ } 0.05 \\
\text { ant @ } 0.05\end{array}$ & \\
\hline
\end{tabular}

(Note: Numbers indicated in parentheses are percentages)

Table 2 shows that 53.14 percent of the faculty members are using the books frequently, 32.84 percent of them are using highly, 9.22 percent of them are using occasionally, and the remaining 4.80 percent are using rarely.

Based on $X^{2}$ values (in Table 2) that there are no significant differences in the level of usage of books available in their libraries between the faculty members of male and female, and arts and science faculty members.

\subsection{Journals/Magazines}

The allocation of faculty members according to their level of usage of journals/magazines in the library, in relation to gender and disciplines is displayed in Table 3.

Table 3: Allocation of faculty members according to the level of usage of journals/magazines

\begin{tabular}{|c|c|c|c|c|c|}
\hline \multirow{2}{*}{ Level of use } & \multicolumn{2}{|c|}{ Gender } & \multicolumn{2}{|c|}{ Discipline } & \multirow{2}{*}{ Total } \\
\hline & Male & Female & Arts & Science & \\
\hline Highly & $\begin{array}{c}38 \\
(21.84)\end{array}$ & $\begin{array}{c}14 \\
(14.43)\end{array}$ & $\begin{array}{c}13 \\
(15.12)\end{array}$ & $\begin{array}{c}39 \\
(21.08)\end{array}$ & $\begin{array}{c}52 \\
(19.19)\end{array}$ \\
\hline Frequently & $\begin{array}{c}68 \\
(39.08)\end{array}$ & $\begin{array}{c}41 \\
(42.27)\end{array}$ & $\begin{array}{c}36 \\
(41.86)\end{array}$ & $\begin{array}{c}73 \\
(39.46)\end{array}$ & $\begin{array}{c}109 \\
(40.22)\end{array}$ \\
\hline Occasionally & $\begin{array}{c}40 \\
(22.99)\end{array}$ & $\begin{array}{c}17 \\
(17.53)\end{array}$ & $\begin{array}{c}16 \\
(18.60)\end{array}$ & $\begin{array}{c}41 \\
(22.16)\end{array}$ & $\begin{array}{c}57 \\
(21.03)\end{array}$ \\
\hline Rarely & $\begin{array}{c}28 \\
(16.09)\end{array}$ & $\begin{array}{c}25 \\
((25.77)\end{array}$ & $\begin{array}{c}21 \\
(24.42)\end{array}$ & $\begin{array}{c}32 \\
(17.30)\end{array}$ & $\begin{array}{c}53 \\
(19.56)\end{array}$ \\
\hline TOTAL & $\begin{array}{c}n=174 \\
(100.00)\end{array}$ & $\begin{array}{c}n=97 \\
(100.00)\end{array}$ & $\begin{array}{c}n=86 \\
(100.00)\end{array}$ & $\begin{array}{c}n=185 \\
(100.00)\end{array}$ & $\begin{array}{c}N=271 \\
(100.00)\end{array}$ \\
\hline $\begin{array}{l}\chi^{2} \text { (Male- Fe } \\
\chi^{2} \text { (Arts- Sci }\end{array}$ & $\begin{array}{l}806 \\
0483\end{array}$ & $\begin{array}{l}\text { TV: } 7 \\
\text { TV: } 7\end{array}$ & $\begin{array}{l}\text { Not Signif } \\
\text { Not Signif }\end{array}$ & $\begin{array}{l}\text { ant @ } 0.05 \\
\text { ant @ } 0.05\end{array}$ & \\
\hline
\end{tabular}

(Note: Numbers indicated in parentheses are percentages)

Table 3 shows that 40.22 percent of the faculty members are using the journals/magazines frequently, 21.03 percent of them are using occasionally, 19.56 percent of them are using rarely, and the remaining 19.19 percent are using highly.

Based on $X^{2}$ values (in Table 3 ) that there are no significant differences in the level of usage of journals/magazines available in their libraries between the faculty members of male and female, and arts and science faculty members.

\subsection{Newspapers}

The allocation of faculty members according to their level of usage of newspapers in the library, in relation to gender and disciplines is displayed in Table 4. 


\section{EPRA International Journal of Research and Development (IJRD)}

Table 4: Allocation of faculty members according to the level of usage of newspapers

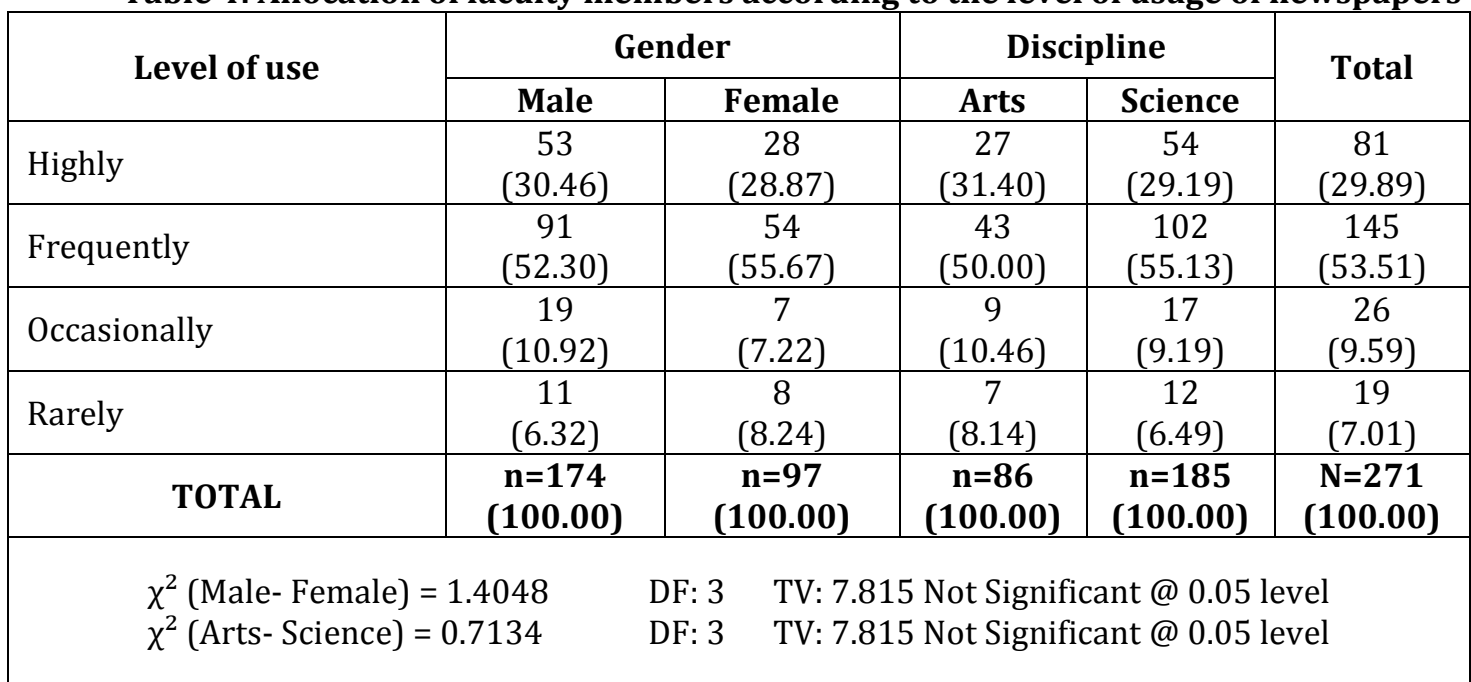

(Note: Numbers indicated in parentheses are percentages)

Table 4 shows that 53.51 percent of the faculty members are using the newspapers frequently, 29.89 percent of them are using highly, 9.59 percent of them are using occasionally, and the remaining 7.01 percent are using rarely.

Based on $X^{2}$ values (in Table 4) that there are no significant differences in the level of usage of newspapers available in their libraries between the faculty members of male and female, and arts and science faculty members.

\subsection{Question papers}

The allocation of faculty members according to their level of usage of question papers in the library, in relation to gender and disciplines is displayed in Table 5.

Table 5: Allocation of faculty members according to the level of usage of question papers

\begin{tabular}{|c|c|c|c|c|c|}
\hline \multirow{2}{*}{ Level of use } & \multicolumn{2}{|c|}{ Gender } & \multicolumn{2}{|c|}{ Discipline } & \multirow{2}{*}{ Total } \\
\hline & Male & Female & Arts & Science & \\
\hline Highly & $\begin{array}{c}47 \\
(27.01)\end{array}$ & $\begin{array}{c}21 \\
(21.65)\end{array}$ & $\begin{array}{c}17 \\
(19.77)\end{array}$ & $\begin{array}{c}51 \\
(27.57)\end{array}$ & $\begin{array}{c}68 \\
(25.09)\end{array}$ \\
\hline Frequently & $\begin{array}{c}88 \\
(50.58)\end{array}$ & $\begin{array}{c}49 \\
(50.52)\end{array}$ & $\begin{array}{c}44 \\
(51.16)\end{array}$ & $\begin{array}{c}93 \\
(50.27)\end{array}$ & $\begin{array}{c}137 \\
(50.56)\end{array}$ \\
\hline Occasionally & $\begin{array}{c}26 \\
(14.94)\end{array}$ & $\begin{array}{c}12 \\
(12.37)\end{array}$ & $\begin{array}{c}11 \\
(12.79)\end{array}$ & $\begin{array}{c}27 \\
(14.59)\end{array}$ & $\begin{array}{c}38 \\
(14.02)\end{array}$ \\
\hline Rarely & $\begin{array}{c}13 \\
(7.47)\end{array}$ & $\begin{array}{c}15 \\
(15.46)\end{array}$ & $\begin{array}{c}14 \\
(16.28)\end{array}$ & $\begin{array}{c}14 \\
(7.57)\end{array}$ & $\begin{array}{c}28 \\
(10.33)\end{array}$ \\
\hline TOTAL & $\begin{array}{c}n=174 \\
(100.00)\end{array}$ & $\begin{array}{c}n=97 \\
(100.00)\end{array}$ & $\begin{array}{c}n=86 \\
(100.00)\end{array}$ & $\begin{array}{c}n=185 \\
(100.00)\end{array}$ & $\begin{array}{c}N=271 \\
(100.00)\end{array}$ \\
\hline \multicolumn{2}{|c|}{$\begin{array}{l}\chi^{2}(\text { Male- Female })=4.8581 \\
\chi^{2}(\text { Arts- Science })=5.8812\end{array}$} & $\begin{array}{l}\text { TV: } 7 . \\
\text { TV: } 7 .\end{array}$ & $\begin{array}{l}\text { Not Signif } \\
\text { Not Signif }\end{array}$ & $\begin{array}{l}\text { ant @ } 0.05 \\
\text { ant @ } 0.05\end{array}$ & \\
\hline
\end{tabular}

(Note: Numbers indicated in parentheses are percentages

Table 5 shows that 50.56 percent of the faculty members are using the question papers frequently, 25.09 percent of them are using highly, 14.02 percent of them are using occasionally, and the remaining 10.33 percent are using rarely.

Based on $X^{2}$ values (in Table 5) that there are no significant differences in the level of usage of question papers available in their libraries between the faculty members of male and female, and arts and science faculty members.

\subsection{Project reports}

The allocation of faculty members according to their level of usage of project reports in the library, in relation to gender and disciplines is displayed in Table 6. 


\section{EPRA International Journal of Research and Development (IJRD)}

Table 6 shows that 28.04 percent of the faculty members are using the project reports occasionally, 21.77 percent of them are using rarely, 21.03 percent of them are using frequently, 16.98 percent of them are using highly, and the remaining 12.18 percent are not using.

Table 6: Allocation of faculty members according to the level of usage of project reports

\begin{tabular}{|c|c|c|c|c|c|}
\hline \multirow{2}{*}{ Level of use } & \multicolumn{2}{|c|}{ Gender } & \multicolumn{2}{|c|}{ Discipline } & \multirow{2}{*}{ Total } \\
\hline & Male & Female & Arts & Science & \\
\hline Highly & $\begin{array}{c}31 \\
(17.82)\end{array}$ & $\begin{array}{c}15 \\
(15.46)\end{array}$ & $\begin{array}{c}14 \\
(16.28)\end{array}$ & $\begin{array}{c}32 \\
(17.30)\end{array}$ & $\begin{array}{c}46 \\
(16.98)\end{array}$ \\
\hline Frequently & $\begin{array}{c}36 \\
(20.69)\end{array}$ & $\begin{array}{c}21 \\
(21.65)\end{array}$ & $\begin{array}{c}19 \\
(22.09)\end{array}$ & $\begin{array}{c}38 \\
(20.54)\end{array}$ & $\begin{array}{c}57 \\
(21.03)\end{array}$ \\
\hline Occasionally & $\begin{array}{c}53 \\
(30.46) \\
\end{array}$ & $\begin{array}{c}23 \\
(23.71)\end{array}$ & $\begin{array}{c}22 \\
(25.58)\end{array}$ & $\begin{array}{c}54 \\
(29.19)\end{array}$ & $\begin{array}{c}76 \\
(28.04) \\
\end{array}$ \\
\hline Rarely & $\begin{array}{c}37 \\
(21.26) \\
\end{array}$ & $\begin{array}{c}22 \\
(22.68)\end{array}$ & $\begin{array}{c}21 \\
(24.42)\end{array}$ & $\begin{array}{c}38 \\
(20.54) \\
\end{array}$ & $\begin{array}{c}59 \\
(21.77) \\
\end{array}$ \\
\hline Not & $\begin{array}{c}17 \\
(9.77)\end{array}$ & $\begin{array}{c}16 \\
(16.50)\end{array}$ & $\begin{array}{c}10 \\
(11.63)\end{array}$ & $\begin{array}{c}23 \\
(12.43)\end{array}$ & $\begin{array}{c}33 \\
(12.18)\end{array}$ \\
\hline TOTAL & $\begin{array}{c}n=174 \\
(100.00)\end{array}$ & $\begin{array}{c}n=97 \\
(100.00)\end{array}$ & $\begin{array}{c}n=86 \\
(100.00)\end{array}$ & $\begin{array}{c}n=185 \\
(100.00)\end{array}$ & $\begin{array}{c}N=271 \\
(100.00)\end{array}$ \\
\hline $\begin{array}{l}\chi^{2} \text { (Male- Fe } \\
\chi^{2} \text { (Arts- Sci }\end{array}$ & $\begin{array}{l}6119 \\
3124\end{array}$ & TV: & $\begin{array}{l}\text { Not Sign } \\
\text { Not Sign }\end{array}$ & $\begin{array}{l}\text { ant @ } 0.05 \\
\text { ant @ } 0.05\end{array}$ & \\
\hline
\end{tabular}

(Note: Numbers indicated in parentheses are percentages)

Based on $X^{2}$ values (in Table 6) that there are no significant differences in the level of usage of project reports available in their libraries between the faculty members of male and female, and arts and science faculty members.

\subsection{Back volumes of periodicals}

The allocation of faculty members according to their level of use of back volumes of periodicals in the library, in relation to gender and disciplines is displayed in Table 7.

Table 7: Allocation of faculty members according to the level of use of back volumes of periodicals

\begin{tabular}{|c|c|c|c|c|c|}
\hline \multirow{2}{*}{ Level of use } & \multicolumn{2}{|c|}{ Gender } & \multicolumn{2}{|c|}{ Discipline } & \multirow{2}{*}{ Total } \\
\hline & Male & Female & Arts & Science & \\
\hline Highly & $\begin{array}{c}29 \\
(16.67)\end{array}$ & $\begin{array}{c}14 \\
(14.43)\end{array}$ & $\begin{array}{c}11 \\
(12.79)\end{array}$ & $\begin{array}{c}32 \\
(17.30)\end{array}$ & $\begin{array}{c}43 \\
(15.87)\end{array}$ \\
\hline Frequently & $\begin{array}{c}48 \\
(27.59)\end{array}$ & $\begin{array}{c}29 \\
(29.90)\end{array}$ & $\begin{array}{c}25 \\
(29.07)\end{array}$ & $\begin{array}{c}52 \\
(28.11)\end{array}$ & $\begin{array}{c}77 \\
(28.41)\end{array}$ \\
\hline Occasionally & $\begin{array}{c}54 \\
(31.03) \\
\end{array}$ & $\begin{array}{c}11 \\
(11.34)\end{array}$ & $\begin{array}{c}8 \\
(9.30) \\
\end{array}$ & $\begin{array}{c}57 \\
(30.81) \\
\end{array}$ & $\begin{array}{c}65 \\
(29.99) \\
\end{array}$ \\
\hline Rarely & $\begin{array}{c}31 \\
(17.82)\end{array}$ & $\begin{array}{c}18 \\
(18.56)\end{array}$ & $\begin{array}{c}16 \\
(18.61)\end{array}$ & $\begin{array}{c}33 \\
(17.84)\end{array}$ & $\begin{array}{c}49 \\
(18.08)\end{array}$ \\
\hline Not & $\begin{array}{c}12 \\
(6.90) \\
\end{array}$ & $\begin{array}{c}25 \\
(25.77) \\
\end{array}$ & $\begin{array}{c}26 \\
(30.23) \\
\end{array}$ & $\begin{array}{c}11 \\
(5.94)\end{array}$ & $\begin{array}{c}37 \\
(13.65)\end{array}$ \\
\hline TOTAL & $\begin{array}{c}n=174 \\
(100.00)\end{array}$ & $\begin{array}{c}n=97 \\
(100.00)\end{array}$ & $\begin{array}{c}n=86 \\
(100.00)\end{array}$ & $\begin{array}{c}n=185 \\
(100.00)\end{array}$ & $\begin{array}{c}N=271 \\
(100.00)\end{array}$ \\
\hline \multicolumn{6}{|c|}{$\begin{array}{c}\chi^{2}(\text { Male- Female })=26.6574 \\
\chi^{2}(\text { Arts- Science })=37.4761 \text { DF: } 4\end{array}$} \\
\hline
\end{tabular}

(Note: Numbers indicated in parentheses are percentages)

Table 7 shows that 29.99 percent of the faculty members are using the back volumes of periodicals occasionally, 28.41 percent of them are using frequently, 18.08 percent of them are using rarely, 15.87 percent of them are using highly, and the remaining 13.65 percent are not using. 


\title{
EPRA International Journal of Research and Development (IJRD)
}

\author{
Volume: 5 | Issue: 7 | July 2020
}

- Peer Reviewed Journal

Based on $X^{2}$ values (in Table 7) that there are significant differences in the level of usage of back volumes of periodicals between the faculty members of male and female, and arts and science faculty members. That means more male faculty members are using the back volumes of periodicals when compared to female faculty members; and science faculty members are using heavily compared to arts faculty members in this regard.

\section{FINDING AND SUGGESTIONS}

1. A majority of the faculty members (53.14\%) are using the books frequently, 32.84 percent of them are using highly, 9.22 percent of them are using occasionally, and 4.80 percent are using rarely.

2. Most of the faculty members $(40.22 \%)$ are using the journals/magazines frequently, 21.03 percent of them are using occasionally, 19.56 percent of them are using rarely, and 19.19 percent are using highly.

3. A majority of the faculty members $(53.51 \%)$ are using the newspapers frequently, 29.89 percent of them are using highly, 9.59 percent of them are using occasionally, and 7.01 percent are using rarely.

4. A greater part of the faulty members $(50.56 \%)$ are using the question papers frequently, 25.09 percent of them are using highly, 14.02 percent of them are using occasionally, and 10.33 percent are using rarely.

5. 28.04 percent of the faculty members are using the project reports occasionally, 21.77 percent of them are using rarely, 21.03 percent of them are using frequently, 16.98 percent of them are using highly, and 12.18 percent are not using.

6. 29.99 percent of the faculty members are using the back volumes of periodicals occasionally, 28.41 percent of them are using frequently, 18.08 percent of them are using rarely, 15.87 percent of them are using highly, and 13.65 percent are not using.

7. There are no significant differences in the level of usage of books, journals/magazines, newspaper, and project reports available in their libraries between the faculty members of male and female, and arts and science faculty members.

8. Majority of the male faculty members are using the back volumes of periodicals when compared to female faculty members.

9. More number of science faculty members are using the back volumes of periodicals compared to arts faculty members.
10. The budget for the purchase of books should be enhanced in proportion to the rising cost of books as well as to meet the increasing demands of the reading community.

11. The existing financial resources for purchase of books are to be utilized in a scientific way based on the needs of the reading community.

12. Subscribe to the core periodicals/journals in various branches only on the basis of user survey results.

\section{REFERENCES}

1. Doraswamy, M., \& Appalaswami Naidu, $V$. (2020).Utilization of Print Resources in Degree College Libraries in Visakhapatnam District: An Analytical Study. International Journal of Management, 11(2), 209-220.

2. Krishna Reddy, M.V., Anjaiah, M., \& Doraswamy, M. (2020). Information use by the faculty members of NAAC accredited degree colleges in Kadapa district: A study. Aegauem Journal (UGC Care List-II), 8(7), 1004-1011.

3. Kusuma Kumari, K., \& Doraswamy, M. (2019). Users Perception on Library Printed Resources: A Survey on NAAC Accredited Degree Colleges in Vijayawada City. International Journal of Research and Analytical Review, 6(2), 592-599.

4. Doraswamy, M. (2015). Customer satisfaction of library print resources in autonomous college libraries: A case study of MBA students. SRELS Journal of Information Management, 52(3), 213217.

5. Doraswamy, M. (2012). Information use pattern towards library services and facilities by the faculty members of Siddhartha Educational Institutions Vijayawada, Andhra Pradesh: a study. International Journal of Information Dissemination and Technology, 2(3), 176-181. 